\title{
Plagiarism in Academic Writing of Bachelor Degree Students at Faculty of Economics and Business in University of Muhammadiyah Magelang
}

\author{
Umi Rachmawati \\ Faculty of Economics and Business \\ University of Muhammadiyah Magelang \\ Indonesia \\ Rachmmwati_umi@ummgl.ac.id
}

Abstract-This study is a case study aimed at gathering data and findings on the plagiarism in academic writing of the university students. It focuses on the action of plagiarism done by many students in their academic writing. It is done to see the recent condition of the students' academic writing in terms of the plagiarism. A lot of students plague their academic writings especially in their final writing to fulfil their degree demand. There should be actions to solve the problems of plagiarism but there must be clear elaborations of the condition of the students' academic writing dealing with plagiarism. This study is on the students' academic writings of the accounting and management study programs at Faculty of Economics and Business in University of Muhammadiyah Magelang in the academic year of 2016-2017. The writings are the students' final examination which determine their final score of the subject English 2. All of the students in the second semester were involved in this study. The data gathering instruments implemented were students' writings test and interviews related to their perspective on plagiarism. The results of this study are (1) there are 90 students out of 389 students plagued their writings $(23.14 \%)$; (2) some of the plagiarists have not understood exactly how they plagued; (3) there are some plagiarists who know what they had done belongs to plagiarism but they still did it; (4) the stakeholder of the faculty gives less attention on the act of plagiarism.

Keywords_Plagiarism; academic writings

\section{INTRODUCTION}

The demand of the current English language learning for the bachelor degree students is the ability to produce any academic texts dealing with their filed. Students are expected to be able to express their performance through their writing. This is aimed at developing the students' skills in not only writing but also the reading skills to face the development of the $21^{\text {st }}$ century. The students of bachelor degree are doing their literature review to strengthen their understanding on their field. Thus, the students are required to perform their abilities in academic writing.

Dealing with the academic writing, there are some considerations that both the teachers and the students to deal with. Two of them are the features of academic writing and the aspect of plagiarism. Features of academic writing is on the writing itself. An academic writing should be written in accordance with the rules of English writing and meet the coherence and cohesion of the writing. The writing should be written in the nature of English writing.

Then, the next aspect is the authenticity of the academic writing. The students of bachelor degree should make their writing original and based on what they have got in their mind. The ideas and the ways of writing and presenting the ideas should be original and authentic. The authenticity of the writing is done through presenting their writer's ideas and the style of the writer's in writing must be different from other writers. Hence, the academic writing belongs to authentic and original and it is free from plagiarism.

The next question is then, why it is important to cover the issue of plagiarism. There are many writers made their writings not free from plagiarism. The limitation of their writing ability and the insufficient ideas and knowledge of the world contribute the most plagiarism activities. The writers are busy on thinking 
on what they need to do to make their writing done in one minute and move to another task. With the free information and technology use in the current teaching and learning, students are getting easier to search, copy and paste any text from the internet and label it as their own writings.

The students are also afraid of making grammatical errors in their writings and it becomes another reason why they plagiarize their writing. Many students of the Faculty of Economics and Business in University of Muhammadiyah Magelang do not have high confidence on their competences in writing through English. They stated that the use of English is confusing and they need to think twice when they write. With the limited time provided by the lecturers on the process of writing, the students prefer to search, choose, copy, and paste the writings written by other authors. They do not realize that they have done plagiarism since they only make time and their complicatedness of English writing as the first consideration.

The next question is whether they know the impact of plagiarism. Some students really concern on this issue but many of them do not. Based on what the researcher has observed during the teaching of English, many students from the Faculty of Economics and Business still neglect this issue. The rising problem might be due to their limit knowledge of the effect of plagiarism. The major loss from conducting plagiarism is the distrust from other people to the next products. People will always assume that the plagiarist will do the same thing on their products even though it is not. Thus, the plagiarists will lose many job opportunities and develop their competence. This is the social sanction which is extremely hard and unaffordable for the doer.

In addition, specifically, for the students of Faculty of Economics and Business, they who do plagiarism will have $\mathrm{E}$ for their final score. The students have to retake the same subject on other opportunity. It means that they will spend more time to do the same thing and it takes more their efforts to finish their study in time. It also requires more money for the students to retake the same class. In short, the students who do plagiarism will have many up-coming problems from their crime.

This study limits the discussion on the issue of plagiarism and the impacts of conducting plagiarism. it will also dig deeper understanding on the reasons for conducting the plagiarism which infers the intention of this issue. Those findings are briefly elaborated in this piece of writing.

\section{THEORETICAL REVIEW}

\section{A. Academic Writing}

It is wise to make equal understanding on the term academic writing before we move on the next part of this writing. Many people have their own definition on the terms academic writing". It is a clear and logical organization of writing which deals as a self-study and reference guide for students needing to work independently. It is commonly for the students who learn English for Academic Purposes. For thorough definition, academic writing is academic assignments which include coursework and take weeks to write and exam answers (Bailey, 2011: 3).

Based on what Bailey has elaborated on the definition of academic writing, it can be concluded that academic writing deals with academic assignments which might have different purposes. Bailey (2011: 3) elaborated some purposes of academic writing; (1) to make report on a piece of research that has been done by the writer, (2) to make answers for questions have been given or chosen by the writer, (3) to discuss a certain interests and provide the writer's view on the topic discussed, and (4) to synthesize studies by other researchers on a certain topic. The four-purpose of academic writing presents the demand and goals of the bachelor degree in which they are required to conduct a scientific investigation on a certain topic of interest and make report on it in such a beautiful way so everyone can understand the findings and contribute on the future studies on the same topic of interests.

Actually, we need to bear more understanding on the definition of writing itself. Writing is a cyclic process of elaborating thoughts and feeling on the writer's idea. It is a process of learning through constructing complete thoughts on a piece of paper (Hibbard \& Wagner, 2003: 56). It deals with opportunities to organize information, and graphic organizers support the process of writing (Hibbard \& Wagner, 2003: 60). There are three main steps of writing form the pre-writing until the production of final draft. Hibbard \& Wagner (2003: 60) shares three process of writing namely accessing and acquiring information, processing the information, and creating the final product. Those steps are depicted in the following figure combined with other factors influencing those steps.

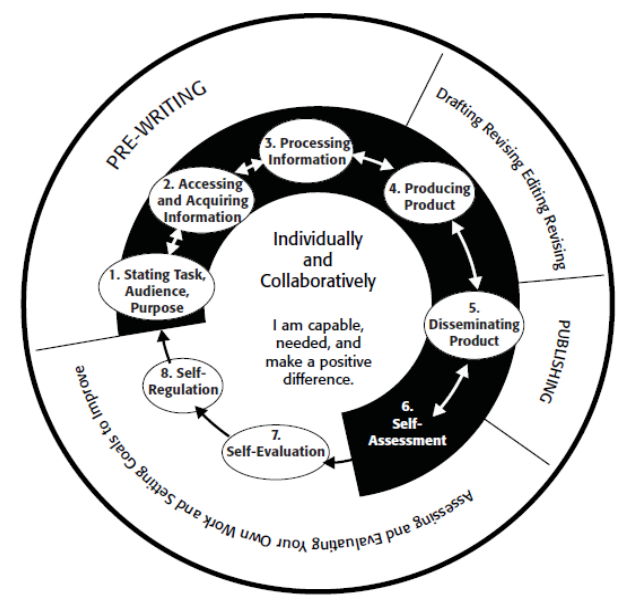

Figure 1. The Cycle of Learning and Writing Process (Hibbard \& Wagne, 2003: 60) 
In the pre-writing phase, there are three steps of preparing the writing. Stating the tasks, audience, and purpose are done to decide what kind of writing they will have and how they will make their writing easily understood by the readers. Next, accessing and acquiring information is done to enrich the students' writing which continues by processing information. Those steps are done orderly to prepare the writing by having sufficient and rich information on the topic of interest.

The next phase is the drafting revising editing revising which involves producing product. This phase is the major step in writing. The students use their previous provisions to produce sophisticated, rich, and understandable writing. Without having good information processed in the previous step, the writer cannot make desired writing as presented in the learning goals.

Then, the step is publishing in which the writer disseminate their writings to the audience through various ways such as journals and proceeding. By this process, the writer will have various responses from the readers which become the writer's self-learning path ways. They will have self-assessment, self-evaluation and self-regulated learning. This step enables the writers to develop their own competences in writing and develop their characteristics through their selfregulated learning.

In spite of the formula or steps of writing academically, the writer should consider some aspects of academic writing. Academic writing is also known as scientific writing which can be defined as precise, impersonal, and objective (Hartley, 2008: 3). Further, it implements the third person, the passive tense, complex terminology, and various footnoting, and referencing systems. The students should be able to produce not only rich text but also precise and lucid and the content should be far from subjectivity and personal to avoid bias.

There are some characteristics of academic writing as propose by Hartley (2008: 4). Academic writing is unnecessarily complicated; pompous, long-winded, technical; impersonal, authoritative, humorless; elitists and exclude outsider. In fact, it also may be appropriate in specific circumstances; and easier for non-native speakers to follow. A good academic writing is expected to have those characteristics to have its clarity and authenticity.

In addition, in composing a good academic writing, the standard structure in facilitation communication through academic writing is known as IMRAD. IMRAD stands for introduction, method, results, and discussion (Hartley, 2008: 8). Introduction is the space for the writer to introduce the whole texts briefly. Method deals with the research method undergone in the academic writing since academic writing mostly a report of a certain study. Results is the findings of the study conducted. Lastly, discussion is the space where the writer express their ideas and thoughts based on the findings on the previous phase. It deals with the writer's creativity, logical thinking, and analytical thinking to synthesize or reconstruct the findings. The whole phases are organized orderly.

Actually the academic writing is considered to be a hierarchy of overlapping processes (Hartley, 2008: 9). The level 1 it is the actual process of writing which is called the keyboarding the text. It is the process of making writing draft which becomes the track of the writing. Then, writing and thinking is the second level of academic writing. It is the protocol analysis or so called technique. It drives who the text is being written for, what it is about, and how much of the text has been already produced (Hayves, 2006 in Hartley, 2008: 10). Lastly, the third level is social aspects of academic writing. It is the view that things facilitate and things inhibit writing both moderated environmental factors and internal factors. Environmental factors are time available to write and the internal factor is the writing fluency. Those levels are hierarchical and the last level is the highest level of all.

Related on the previous discussion, the writers should also make some considerations in their writing. Those considerations are audience, purpose, organization, style, flow, and presentation (depicted on figure 2). Writers have to consider the audience who will consume the writing and might be knowledgeable about the topic. The audience, purpose, and strategy are correlated in which the writer's purpose might be different from the audience. The organization of the academic writing views in a structured format. It enables the readers to follow the texts through predictable patterns. The style of the academic writing must also proper which is consistent, proper messages conveyed, and written in formal English which actual ideas and data. Then, moving one statement to the next establishes a clear connection of ideas which can help the readers follow the text. Hence, flow is being considered in the academic writing. The last is presentation which deals with errors of the writing both written by nonnative and native speakers. The writer considers the overall format, proofread for the careless grammar mistakes, and check for the misspelled words. Those aspects are drawn in the following figure.

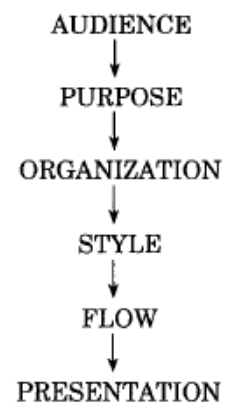

Figure 2. Consideration in Academic Writing (Swales \& Feak, 2001: 8). 
Th concept of academic writing is still under discussion and for the summary, academic writing is scientific writing as a report of any scientific. It considers some aspects of academic writing namely audience, purpose, organization, style, flow, and presentation. It also needs the writer to have a structured pathway on the content of writing academicly that consists $\mathrm{o}$ introduction, method, results, and discussion. it is clear enough that writing academic text requires not only the knowledge of the wolrd but also knowledge of the language.

\section{B. Plagiarism}

The further discussion is on the definition of plagiarism. Many are still confused on the term plagiarism. Some of them believe that plagiarism is doing a hundred percent copy and paste. Some believe that plagiarism means that they are not allowed to write anything in the same idea or thought. Some also understand that plagiarism is changing some words from the original ones.

Therefore, there are some understanding of plagiarism. Plagiarism is merely understood as a violation of the rules and widely conducted ethical principles, especially in the act of language use (Pecorari, 2010: 1). Pecorari also adds that plagiarism does not only about the plagiarized texts but also threatening for other texts. Textual plagiarism is the implementation of words and/or ideas from other sources with no appropriate attribution (Pecorari, 2010: 4). Plagiarism involves a set of behaviors dealing with the variety of ways and natural language used in society (Blum, 2009: 12). It is clear enough that plagiarism is cheating someone's works without giving any credits.

Jones et al (2005) in Neville (2007: 28) contributes some definitions of plagiarism. (1) Collusion with no official approval among students with the result that identical or close to it, is presented. (2) The existence of falsification in which the content of assignments was invented or presented by a certain student as their work. (3) It is replication in which a student do same or similar work on more than one occasion to achieve academic credits. (4) Plagiarism takes unauthorized notes into an examination. (5) Plagiarism contains an unauthorized copy of an examination paper. (6) Plagiarism includes communication in examination to help or be helped wit answers. Lastly, (7) impersonation of other persons during the examination.

To have clearer understanding on the act of plagiarism, Neville (2007: 28-9) proposes three main forms of plagiarism. First, plagiarism by copying another person's work which includes the work of another students and claim or pretend it is as theirs. The second, plagiarism is presenting arguments using a blend of own ideas and significant percentage of copied words without acknowledgment. The last, plagiarism by doing paraphrasing another work but not giving acknowledgement to the original writer or organization. Those three forms of plagiarism represent the interpretation of plagiarism understanding by the writers.

In the era of $21^{\text {st }}$ century, plagiarism is becoming easily conducted by many students all over universities in the world. Students are getting easily to cheat and the way they cheat is interesting and sophisticated that express guilt or remorse (Lathrop \& Foss, 2000: 1). With the use of new technology, students have broader opportunities to access various texts and it tantalizes the students to do the criminal due to some reasons. As what Dennis (2005) found on a reasons of cheating in 80 students. Mostly it is because they started too late and ran out of time and do not do the coursework and less mastering the materials.

With the threats of conducting plagiarism, the main attention is on how to avoid plagiarism. Neville (2008: 35-8) shares their ways of avoiding plagiarism. Summarizing and paraphrasing are ways of avoiding plagiarism. Summarizing is retelling the main or general idea of the text. While paraphrasing is on particular things which involves particular section attention of a text and attempting in one's own words which is aimed at capturing the essence of the original.

Sutherland \& Smith (2008: 70-3) propose six elements of plagiarism. Element 1 is an object which deals with language, words, and texts. The second element is on which has been taken or borrowed or stolen. Element three is from a particular source such as textbooks, journals, students' works, lecture notes, visual materials, images, and the like. Next, element four is by an agent which means that the agent of plagiarism is an individual or students. The fifth element is without adequate acknowledgement to the authors of the sources used in the text. The last element is and with or without intention to deceive. These elements are important to be considered by the teachers to limit the students in plagiarism.

\section{Adults Language Learners}

There are some definitions of adult learners. adult learners are different from young learners who might need more elaborated treatments to succeed the teaching and learning processes. This is due to the condition that adult learners have different characteristics in learning language. Harmer (2001: 40) provides some of adult leaners' characteristics. Adult learners can have interaction with abstract thought. Such characteristic makes the teachers not to create various games and songs during the whole class. A certain game can be done as the refreshment. In addition, adults also have a whole range of experiences in their life to draw on. From the experiences, they will have their own desires about their learning processes and it might have been set on their own. Adult learners also have realized their own responsibiliities so they tend to be more discipline and struggle for their 
boredom during the lesson. With this condition, adults need more various activities during the lesson to enrich their life experiences. Lastly, adults always realize why they need to attend a certain class. They always have clear understanding on what they are learning and what they want to learn o get during or after the class.

Students of bachelor degree in their first semester are in the age of teen which are around seventeen and eighteen (Brown, 2001: 91-93). At this ages, students are categorized as teenaged learners who have different characteristics as what children and adults have. Teenagers are in the age of puberty and they need simpler or brief explanation of the materials they are learning. If the teachers provide more complex and terrible instructions, it can change the learners' behavior on something. Confusion, self-consciousness, growing, and changing bodies and minds might be ninety degree different as the learners are in the condition of terrible teens. It is because teens are in the stage of between children and adults. They need more consideration in their language teaching.

The success of teaching and learning does not only merely on the considerations that the teachers consider before, during, and after the teaching but also the teaching writing model. Uppstad and Wagner (2006: 225-7) have developed an alternative model for the teaching of writing based on some philosophical views in language teaching. The first step is thinking-forwriting which is language-specific. It relate writing and cognitions while both relativized and operationalized. The relativized is from a universal perspective. The second step is the notion of skill. Teachers need to really understand the notion of skills before they select what kind of skills will be trained during their teaching. Skills are used with cognitive participation. Cognitive participation requires good insights which is influenced by the students' reading. For short, writing ability is influenced by the reading profile which also deals with creativity in writing and reading viewed as automatic behavior.

One more important aspect of the teaching of writing is the idea of students' style in academic writing. Style is understood as distinction, also convention, creative or even customary, as a mark of individual or communal identity (Schick in McDonald \& McDonald, 2002: 238). Style is how people differ each other with her/his creativity to mark his/her identity. Therefore, academic writing is broad and everyone has a certain style which figures out his/ her creativity and identity. This aspect should be considered by the teachers when they prepare, conduct, and evaluate the teaching of academic writing.

In addition, technology also influences the teaching of writing since it give direct and huge impact on the students' writing. Technology offers its easiness and effectiveness of data collection, information collection, and their interpretation which are beneficial for the students. Teachers need to well organize their students in using such technology. Directing to the discussion of this paper, technology offers broad opportunities for the students to conduct plagiarism. Thus, teachers are required to be more careful and thorough in evaluating the students' writing.

\section{Research Method}

This study was a case study conducted in accounting and management study programs at Faculty of Economics and Business, University of Muhammadiyah Magelang. Case study is a particular instance frequently designed to give illustration on a more general principle (Nisbet and Watt,1984: 72). The whole students in the first semester majoring accounting and management study programs were involved in this study. This study is aimed at providing deep and wide elaboration on the subject taken which depends on the context and is correlated to the ideas and principles of the subject discussed. There are some principles of the implementation of a case study as noted from Hitchcock and Hughes (1995: 322) as presented below.

a. Case study is concerned with a rich and vivid elaboration of events relevant to the case.

b. Case study shares chronological narrative of events dealing with the case.

c. Case study blends an elaboration of events with the analysis of them.

d. Case study focuses on individual actors or groups of actors, and seeks to understand the perception of events.

e. It highlights specific events relevant to the case.

f. The researcher gets involves in the case.

g. An attempt is developed to give portrait of the richness of the case in writing up the report.

Based on the brief elaboration above, it can be understood that a case study is a set of temporal, geographical, organizational, institutional, and other contexts enabling boundaries drawn around the case. The case was done to get both the qualitative and quantitative findings of the implementation of the digital reading assessment towards the students of accounting and management study programs at University of Muhammadiyah Magelang. This study was based on the subjects and might provide different results from different subjects. The main concern of this study is on the students' views on plagiarism, factors affecting this behavior, and how this can happen. 
This study was done in 2017 in the even semester during January until May 2017. The subjects included the second semester of accounting and management study programs at Faculty of Economics and Business, University of Muhammadiyah Magelang. The data collected was done through writing test results, observation and interviews. The writing test results were done on to measure the plagiarism activity which had been checked by online plagiarism checker. Observation was done during the assessment of some classes of the study programs mentioned. The interviews were done both to the lecturers and the students. The results of the data were analyzed qualitatively and quantitatively. The quantitative data were analyzed through descriptive quantitative and the qualitative data were analyzed through the use of qualitative analysis.

\section{DISCUSSION}

Based on the research procedure elaborated in the previous part, there were some steps have been conducted. The writing tests and the interviews were done to find more lucid data and interpret them. The writing test were a task done at the end of the even semester. The writing task was on the critical analysis on cultural issues related to English language learning. The students were required to choose a certain topic and make critical analysis based on what they have understood. The writing should be written in only two pages and written in good English. The scoring of the writing was through the use of writing rubric but the most essential scoring aspect is the authenticity of the writing. The less plagiarism of the text is, the better score they will have. To check the authenticity of the writing, the researcher used online plagiarism checker which is trustable and reputable.

From the data of the students' writing and the results of the plagiarism checker, there were many students who plagiarized their texts. There are 389 students enrolled in this study and there are 90 students who plagiarized their texts. Actually there are three types of results found in the use of online plagiarism checker. Those are significant plagiarism, detected plagiarism, and no plagiarism detected. The 90 (23, $14 \%$ ) students were the students who made significant plagiarized writings.

In relation to the plagiarism results, the researcher conducted interviews to gather any information on the factors affecting the students' behavior and provide solution to limit this attitude. There are some students who did the plagiarism were interviewed. Based on the interviews, the most reason for plagiarism is due to the limited language knowledge and content knowledge. Some of them do not know how to make good English texts and they were reluctant to learn something new or something they have not understood. It means that the students do not have high motivation in learning English. Then, the students felt that the duration of the writing project is too limited since they were in fasting month and there were Lebaran days which took their time at most to visiting each other. In fact, it is an unreasonable explanation.

Dramatically, many students also did not realized how they could plagiarize. They thought that their writings were authentic and far from plagiarism. This means that they have not understood the term plagiarism and how to avoid it. In fact, the previous semester, first semester, the students have got the academic writing which deals with writing processes including avoiding plagiarism. The lecturer has elaborated how to avoid plagiarism by doing summarizing and paraphrasing and also providing acknowledgement to the authors.

However, some students also shared that they have known that to avoid plagiarism, they need to summarize and paraphrase but they do not have good execution for it. Many of them told that they only changed some words and keep the main sentences in the text. They copied and changed some words and they thought that it was safe from plagiarism. Moreover, many of them also have known well that they did plagiarism but they still did it. It is because of the previous reasons elaborated above. Time and complicatedness of the writing persuaded them to do plagiarism.

The whole reasons for conducting plagiarism contribute a big question whether the students have understood the plagiarism. This condition must be reflected from the surrounding. It is bias that the university and the faculty have facilitated the information gap of plagiarism. There should be clear elaboration and support from the learning environment dealing with plagiarism. The students need to have deeper understanding and implementation of avoiding plagiarism. The moral value of honesty and independence should be more highlighted to the students to enable them think better and wiser especially to decide which activity is the best and worst. A kind of seminar of plagiarism can be done to give broader views on the implementation of plagiarism. The university can also provide more opportunities for the students to train themselves how to do paraphrasing and summarizing and also giving acknowledgement to avoid plagiarism. This can be done through guiding the lecturers to always consider paraphrasing, summarizing, and giving acknowledgement on their citation.

The most underlying aspect of plagiarism is the moral values of honesty and respecting others. It seems that controlling the students' work by checking their originality of their writing and providing more opportunities for the students to practice avoiding plagiarism are enough. Maintaining the students' moral values of honesty and respecting others will be such a 
useful idea to encounter this problem. By having high value of honesty, the students will always think again and again to become a tiar". They will keep their behavior in manner to be more honest in doing every single activity. Then, respecting others will also require the students to behave in manner and properly in treating others. They need to make sure that they do not take other's priorities. They have to respect other's opinions, ideas, thoughts, and insights. Those aspects can be highlighted by not only the teachers but also the parents who are assumed as longer companion for the students especially during their home time. Parents can engraft the students by becoming role models for honesty and respecting others. It can cleanse the students' thought to have better attitude dealing with honesty and respecting others.

\section{CONCLUDING REMARKS}

It is clear enough that plagiarism is important and it is essential for the education parties, especially, lecturers, parents, and students to deal with this issue. Plagiarism is demanding and it can affect students' personality in terms of originality of their works. Highlighting the skills of paraphrasing, summarizing, and giving acknowledgement on the authos can decrease the plagiarism done by students. Then, the students need to have support from not only the university but also the family to have higher level of plagiarism awareness. The enrichment of the moral values of honesty and respecting others can be one of the solutions in avoiding plagiarism.

\section{References}

[1] Bailey, Stephen, Academic Writing: a Handbook for International Students. New York: Routldge. 2011.

[2] Blum, Susan D. My word: Plagiarism and college culture. New York: Cornell University Press.. 2009.

[3] Brown, H. D. Teaching by principles: an interactive approach to language pedagogy. New York: Pearson Education. 2001.

[4] Dennis, L.S. Students attitudes to plagiarism and collusion within computer science University of Nottingharm. 2005.

[5] Harmer, J. The practice of English language teaching. : Longman Publishing Inc. 2001.

[6] Hartley, James. Academic Writing and Publishing. New York: Routledge. 2008.

[7] Hibbard, K. Michael \& Wagner, Elizabeth A. Assessing and Teaching Reading Comprehension and Writing. New York: Routledge. 2003.
[8] Hitchcock, G. and Hughes, D. (1995) Research and the teacher (second edition). London: Routledge.

[9] McDonald, Christina R. \& McDonald, Robert L. Teaching Writing: Landmarks and Horison. Illinois: Southern Illinois University. (2002).

[10] Neville, Colin. The complete guide to referencing and avoiding plagiarism. England: Open University Press. 2007.

[11] Nisbet, J. and Watt, J. (1984) Case study. In J. Bell, T. Bush, A. Fox, J. Goodey and S. Goulding (eds) Conducting Small-Scale Investigations in Educational Management. London: Harper \& Row,79-92.

[12] Pecorari, Diane. Academic writing and plagiarism: a linguistic analysis. New York: Continuum International Publishing Group. 2010.

[13] Sutherland, Wendy \& Smith. Plagiarism, the internet and student learning. New York: Routledge. 2008.

Uppstad, Per Henning, and ÅSE KARI HANSEN WAGNER. Approaching the Skills of Writing. Writing and Digital Media (2006): 221. 